\title{
Ottoman forestry: socio-economic aspect and its influence today
}

\author{
Otomano florestal: aspecto socioeconômico e sua influência hoje
}

\author{
Sezgin Özden ${ }^{I}$ Üstüner Birben ${ }^{I I}$
}

\begin{abstract}
Forestry is an important subject because it supplies wood and timber for direct human consumption, in addition to its positive effects on global warming and on bio-diversity, with a history dating back to antiquity. As a labor-intensive sector in developing countries, it maintains interactions with natural resources management, public relations and socio-economic structure. It can affect the prosperity of countries either positively or negatively. Hence, an analysis of the history of forestry bears importance because it not only sheds light on its past and present condition, but also explains the improvements for the protection of forests. Accordingly, in the first section of this study, general information on the Ottoman Land System and Ottoman Forestry Organization will be given. In the second section, we will treat $19^{\text {th }}$ century westernization movements, as well as socio-cultural and economic changes. The third section will include significant regulations on forestry, forest management, and administration in the Ottoman Empire; as well as the influence of Ottoman forestry on the actual socioeconomic structure. In the final section, under the title discussion and conclusion, Ottoman forestry will be examined regarding its consequences in terms of policy, economy and law.
\end{abstract}

Key words: Ottoman, socio-economy, history of forestry, law.

\section{RESUMO}

A silvicultura é um assunto importante, pois o suprimento de madeira em geral e madeira para consumo humano direto, além de seus efeitos positivos sobre o aquecimento global e sobre a diversidade biológica, trata de uma história que remonta à antiguidade. Como um setor de trabalho intensivo nos paises em desenvolvimento, mantém interações com a gestão dos recursos naturais, relações públicas e estrutura socioeconômica. Ela pode afetar a prosperidade dos países, seja positiva ou negativamente. Assim, uma análise da história da silvicultura tem importância, porque não só lança luz sobre a sua condição passada e presente, mas também explica as melhorias para a proteção das florestas. Assim, na primeira parte deste estudo, serão dadas informações gerais sobre o Sistema de Terras e Florestas e Organização Otomano. $\mathrm{Na}$ segunda seção, serão tratados movimentos da ocidentalização do século 19, bem como alterações socioculturais e econômicas. A terceira seção irá incluir regulamentos significativos na silvicultura, manejo florestal $e$ administração no Império Otomano, bem como a influência da silvicultura Otomano na atual estrutura socioeconômica. Na seção final, no âmbito da discussão do título e conclusão, a silvicultura Otomano será analisada em relação as suas consequências em termos de economia, politica e direito.

Palavras-chave: Otomano, socioeconomia, história da silvicultura, lei.

\section{INTRODUCTION}

Forests are no doubt one of the foremost richness of nature on earth. The forest is an element concerning life, health, and the security of the countries; it increases the sheltering capacity for man, is a criterion of civilization, and besides, is directly connected with various economic activities. Moreover, as all these products and services are expected from forests (ANONYMOUS, 1973) it is necessary to preserve and utilize them according to the principles of sustainable development.

${ }^{\mathrm{I} C a n k i r i ~ K a r a t e k i n ~ U n i v e r s i t y ~ F a c u l t y ~ o f ~ F o r e s t r y ~ D e p a r t m e n t ~ o f ~ F o r e s t ~ E c o n o m i c s, ~ 18200, ~ C a n k i r i, ~ T u r k e y . ~ E-m a i l: ~}$ ozden@karatekin.edu.tr

IIstanbul University Faculty of Forestry Department of Forest and Environment Law, 34473, Bahcekoy, Istanbul, Turkey. 
Within the scope of this study, the socioeconomic data actually points out the persons demanding or interested in forestry resources, as well as the matters between the society and the forestry sources are explained (GÜMÜ ,2004). As the utilization of forestry resources, and socio-economic processes that regulate this utilization and restrict it if necessary, have influence over forest utilization in the direction of sustainable development principles, the problem grows even more important. At this point, our objective is to reveal the interaction between socio-economic processes and forestry resources. To attain this goal, it will be useful to understand the past process.

According to a Turkish proverb, "one should know his past well, in order to better comprehend today" (ANONYMOUS, 2005). This saying bears some notable significance as a guidance regarding the problems of present Turkish forestry situation, and the manifestation of solutions for these problems. As for our subject, the relation between man and forest is as old as mankind (ÖZDÖNMEZ, 1964), for the relation of man between forest and tree begins at the very moment he opens his eyes to the world (USLU, 1973). Tribes of hunters and gatherers sustained their life depending on nature, lived on what natural environment provides them, and hardly put down any efforts to change the surrounding world (ERKAN, 2004). The first habitations took place in areas near the forests, and men easily made use of the latter. As the population grew gradually, men needed more agricultural and forestry products, and this evolution went against the forests (USLU, 1973). Today, the principal reason that half of Turkish forests are damaged is the unplanned utilization of Anatolian forests with neither any sustainability principle in the past, nor any consideration regarding possible future consumption of the resource. Hence, to better understand the past, in the upcoming parts of our study, we will focus on land ownership and forestry during the Ottoman times. Forest-public relation in Turkey is not at the desired level. While one reason for this is rural poverty the other is a historical social approach. Forests in Ottoman period are considered by society as God-given. Traditionally the community still wants to take advantage of them freely. Our main aim is to examine the reflection of the historical utilization culture on to today's society. It is not possible to produce new strategies without knowing the historical process about forest-public relations. In order to better understand Ottoman forestry, it is necessary to give some general information about Islamic Law and the Ottoman land system.
Land ownership under Islamic Law and in the Ottoman Times

According to Islamic Law, God is the true owner of any property. Hence, persons are merely figurative proprietors. The Muslim Prophet also appreciated private property. Back in those days, it was accepted to pay "ö ür" or "haraç" for the land one owned (BINGÖL, 1990). Öşür is a kind of Islamic land tax. By taking the land fertility into account, $1 / 10$ of the crop was collected as obligatory alms of property. Here the government interfered for a social objective so that one tenth of the product was distributed to the poor and the people in need. The tithe was out of question during harvestless years (İMAMO LU, 2006). Haraç was collected from non-Muslim citizens. It consisted of two parts. The first one was called "cizye" or a "head tax" and was collected from healthy men. The second one depended on both product revenue, paid in kind, and land acres, paid in cash. In short, for the first one, the tax is paid by person, whereas in the second one, the tax is paid by both product and land (SEV , 1953). In Islamic Law, lands that became or belonged to public property were acquired through conquered areas, or the transfer of owned lands to the state at the end of internal changes, depending on certain conditions. The way the lands were obtained whether through war and peace affects the judicial state of the land. Concerning the lands gained by war, it was the head of state who decided their legal status. The head of state could either make the gained lands private property by "öşür" (Islamic tithe), or left them to non-Muslims as "haraç" lands, or even could release it to persons via "ikta" (In Islamic Law, assignment of only the annual tax or "öşür" of a state-owned land to a person was possible in return for a service) (UZUNÇAR ILI, 1970) as stateowned lands, in exchange for administrative or military duties. As for the lands acquired via peace, the government collected "ösü̈r" or "haraç" depending on the religion of persons to whom the lands were given; and they could also be left to their former owners as "haraç" giving lands (BAYRAKÇI, 1990). Although there are not clear historical resources on the ownership of the forests in Islamic law, forests belong to where they are subject to the ownership of land can be said.

The Ottoman civil administration was feudal in nature. The Empire was based on military principles, and it was divided to states with their governors called "Beylerbeyi", and to districts "Sanjaks" with their chiefs called "Sanjakbey" (KÖPRÜLÜ, 1948) Through the accomplishment of their duties, these civilian authorities made use of "dirlik" lands which were given to military administrative class under their disposal by Sultan. In these dirlik lands, the "rakabe" (bare ownership) 
of the land belonged to the state, while its tenure was under personal property. The person used the land at will, paid tithe, could hand over or sold his tenure; but in order to realize all these actions, the governor's approval and attendance were obligatory. There were five types of Dirlik lands: Has (Large Fief) was the lands given to Sultan, to persons appertaining to the sultanate, to the viziers and to the beylerbeyis. For every five thousand akches, one private soldier was taken to war; Zeamet: It was given to chamberlains in the state, and to the alaybey (troop chief), the castle commander, and other Zaims (Zeamet owners); Timar (Small Fief) included the lands with a revenue between three thousand and twenty thousand akches. For every three thousand akches, one private soldier was taken to war. Some notable types were e kinci (state soldier going to war) timar, guardian timar, and service timar; Yurtluk meant the authorization transfer regarding the tithe of some villages and boroughs, in order to meet salaries and expenses of officers and guardians of shipyards and castles; Ocaklık was similar to yurtluk. In addition, this included the collection of a head tax, which was a kind of tax taken from non-Muslim citizens in Islamic countries, and the collection of customs duties. Dirlik system was in operation until the Tanzimat, the Ottoman period of modernization and reformation which started in 1839 by the Noble Edict of Gülhane in 1839(B NGÖL, 1990)

The timar system-which was indicated as an original and successful basis of sustaining a great and mighty state in an agricultural economy where the transport facilities were limited; the financialbureaucratic organization, method and means were insufficient; and a very small part of the national income that conducted through monetary means was the first and most important financial phase regarding the Ottoman financial methods. Thanks to this system, not only did the smooth functioning of various public services and their synchronization with actual financial and economic resources become possible but it also assured the protection of the labor force, of economic resources or of taxpayers who constitute the source of taxation, by keeping them in indirect conservation terms. As long as the timar-owner lived and continued his task, he would maintain the source of taxation assigned to him in return for this task. Therefore, for the improvement and progress of the system, the timarowner protected the people. Moreover, he could collect taxes easily and without any cost as there were no mediators, and the appearance of any hanger-on group was prevented by assuring the coherence of services and of taxes. All these were the main characteristics of the system. By stressing on the coherence between public services and tax liability as two mechanisms supporting each other, the timar system seemed to have been blended with the Ottoman civil order such that they recall one another (GENÇ, 2009).

The first classification of the Ottoman lands being regarded as property dates back to the Land Code of 7 April 1858. The Code consisted of 103 articles and included various definitions and prescriptions about land operations for the first time. It determined the boundaries of villages and towns and authenticated this situation. There was an effort to cultivate and not to desolate the lands. Title deeds were handed to the rightful owner (GÜNAY, 2003). The Land Code divides the lands to five following types: Arazi-i Memlüke (Private lands): Lands on which the real and juridical persons had all rights of disposition and access, including ownership; Arazi-i Miriye (State-owned lands): Lands the ownership of which was left to the state and the disposition right had been transferred to landowners. They were inheritable, transferable, and could be sold; but the actual land could not be changed, downsized or expanded; Arazi-i Mevkufe (Endowment lands): According to the endowment law, they were the lands endowed for various purposes such as science, religion, charity and such; Arazi-i Metruke (Assigned lands): Their ownership belonged to the state. They were the lands left over to state, village or townspeople. They could not be transferred to private ownership. They were not included in Islamic law, and came in effect by Ottoman Land Code; Arazi-i Mevat (Dead lands): Lands unavailable for agriculture. After an improvement process, they could become private or state-owned land (KÖPRÜLÜ, 1948).

Before the Forestry Regulation, the lands covered by forests were also evaluated according to the above-mentioned landownership status, and the forests have been subjected to a classification strictly connected with Ottoman landownership, as follows: Shipyard and Armory Forests, the possession of which belongs to the state; Forests belonging to villages and townspeople; Private forests; Foundation forests; Cibal-i mübaha (literally, mountains lawful to utilize), forests available for public use.

Understanding Cibal-i Mübaha, which formed a great part of the Ottoman Empire forests, will gain us insights of the system regarding its utilization, and the social and economic pressure heading due to the abolition of the system, as well as the devastation of forests following abolition.

Cibal-i Mübaha: We come upon the concept "Cibal-i Mübaha" for the first time in the Land Code dated 7 April 1858. The concept, however, was not born on this date, and already existed (TOYGAR, 1964) 
as we see from some historical certificates as follows: "Sultan Suleiman Eternal Code, part on forestry, year 1551; in case a hamlet habitant, who is a descendant of the Prophet, cuts tree from the Cibal-i Mübaha, and sells them. As sipahi, can he be able to demand ö ür (tithe) from the hamlet habitant? The response: As it is free, sipahi cannot demand." (KUTLUK, 1948). The articles 1253 and 1259 of Civil Law affirmed that the utilization of Cibal-i Mübaha was permissible without any tithe, just as such of air and water. Nevertheless, it is decreed that in these areas, no opening could be realized and no one would be given any deed (Article 92), that everyone could unconditionally make use of Cibal-i Mübaha for firewood and lumber (Article 93), and that no plantation could be established on these lands by any means (Article 104)(B NGÖL, 1990). Even though some articles about Cibal-i Mübaha existed in the Land Code, it was not indicated which land type these forests would belonged in. The status of Cibal-i Mübaha, which was accepted as state owned by the Forestry Regulation in 1870 , and which we call as public forest in the present day, still remains unsolved in the Land Code. While KÖPRÜLÜ (1948) affirmed that these forests were not included in land types within the Land Code, BARKSIZ (1957) indicated that these lands existed in the Dead Lands. In contrast GÖKTÜRK (1945), argued that "just like large forestlands, as they did not belong to private property, and regarding the spirit and philosophy of the Land Code, there was no objection to accept the vast public land among the state-owned lands."

Even though Cibal-i Mübaha beared such attributes of state-owned lands, it was distinguished from other kinds of the latter, for it could neither be abandoned nor given to another disposal. Cibal-i Mübaha was a kind of state-owned land; on the other hand, the utilization of these forests was decidedly free.

SedatAYANO LU defined Cibal-i Mübaha as "Forests, which were no one's property, utilizable unexceptionally freely under the verdict and disposal of State, and not assigned to the needs of shipyard, armory or any other imperial requirement." (AYANOĞLU \& B RBEN, 2008)

The current forest property is no doubt subject to a similar situation. In Turkey, while the bare ownership of public forests belongs to the state, their utilizations have been granted to the entire society. According to Article 169 of 1982 Constitution, the government maintains the right of supervision and surveillance over all forests in country; regarding their protection, forests are accepted as derelicts due to public property theory, and thus, their handover to private property has been prevented.
Westernization movements in the early $19^{\text {th }}$ century and the evolution of Ottoman forestry

As the genuine social and economic order of the Ottoman Empire, which worked very well until the end of Suleiman the Magnificent era, gave way to certain corruptions due to several domestic and external reasons, the westernization efforts notably increased beginning from the $18^{\text {th }}$ century (ASLAN \& YILMAZ, 2001). The Western restructuring process also influenced the Ottoman Empire, and led to the Westernization period. The principal motives of these westernization movements were the advent of constitutional governments and nation states in the West, as well as capitalism and the new scientific approach, which concentrated on experiment and observation, and was supported by rationalism (MUTLU, 2006).

During the Tanzimat period, habitants within the borders of the Ottoman Empire and especially in metropolises were subjected to fast social and cultural change. Dualities regarding the old and the new began to arise in every domain of life (GÜNDÜZ, 2002). In those days, social and cultural evolution, and the economic dependence on other countries began to mold government policies. The forestry sector could not avoid these changes and was exposed to important developments. During the Tanzimat period, some radical changes were realized with respect to forest property, as well as forest management and administration. The Ottoman interest to the forests was limited to military requirements until the midnineteenth century. Apart from the reserved forests for the Tersâne (The Imperial Dockyard) and Tophâne (The Imperial Arsenal), the forested lands were open for unlimited public usage and had hardly protection (KESKİN, 2010)

Before the Declaration of the Tanzimat, we do not come upon radical measures by the Ottoman Empire on the subject of forests, forest care and recultivation. Decisions taken on the matter consist of a few narrow-scoped decrees and some code verdicts (D KER, 1947). The Ottoman Forest Regulation, which was valid by 1937, was put into effect in the era of Tanzimat( Reforms). This regulation contributed profoundly to the improvement of the Ottoman forestry system (KOÇ, 2005) Nonetheless, the Ottoman Empire began to consider forests as an economic value and to manage them only after the Tanzimat, at the end of Crimean War in 1856. According to MORAWITZ (1978), the Ottoman Empire applied to England for an external loan of 1,000,000£. English Army responded that they are ready to lend the sum in exchange for lumber, wheat and copper, but in the end, as the calculation of these 
articles by the Ottoman Empire took a very long time, they could not attain the loan. It is known that the firstever external debt of the Ottoman Empire was the one taken during the Crimean War (YILMAZ, 2002). Back then, putting forward the war as a reason, the Empire asked its ally France for a loan. The French, however, said they could not lend any money, and mentioned that the revenues of the Ottoman Empire would come via forests (KILIÇ, 2004). At the end of improving bilateral relations, several French forest experts were brought to the Ottoman Empire, and worked in the Empire for nineteen years, from 1858 to 1876 . Tassy, Stème, Bricogne, Gallmiche, Godchaux, Chèrvau, and Simon are among these experts. Back then, these experts examined the Ottoman lands in Europe, as well as on Aegean islands, and also the forests whose lumber could be easily sold. In addition, the forests in and around Sinop, Kastamonu, Mount Ida, Konya, and Karaman had been evaluated (BERNHARD, 1935).

The biggest impact of the above-mentioned experts on the forestry of the day was to lay a foundation for forest administration, and the Forestry Regulation. After the Declaration of the Tanzimat, the state clearly began to pay more and constant attention to forests, and to consider them as a source of income. Thereupon, in the years 1839-1840 the Forestry Department, which was attached to Ministry of Trade with headquarters in Istanbul, was established to prevent the idle utilization of forests, and to execute processes with respect to gathering forestry incomes. In 1869 , forestry works were centralized at a forest management department that was established under the Ministry of Finance in Istanbul. The organization consisted of a general manager, an assembly, and a secretary. In 1870, with the implementation of Forestry Regulation, the provincial institution of forestry organization was established, for Article 1 of this regulation indicated that the technical and administrative activities in all forests should be carried out by General Directorate of Forestry (EK ZO LU \&AKESEN 2006).

Forestry Regulation dated 1870 bears some special importance, as it is the first ever law text on forestry. By the Regulation, the forests were classified according to land ownership as: Forests directly belonging to the government; Forests belonging to endowments; Coppices belonging to towns and villages; and Private forest. This classification manifests that the valid property regulation before 1870 still continues. With the regulation, the forests were divided into four in respect to property. However, the regulation included the verdicts concerning only public and endowment forests, and village and town coppices. Therefore, the operations related to administration of private forests have been left over to verdicts of the Land Code. By the Regulation, all forests called as the imperial forests, the shipyard armory forests, the stateowned forests and Cibal-i Mübaha are gathered under the name of forests belonged to the state, and the Cibali Mübaha concept, which has had negative effects on forests for a long time, has become history judicially (TOYGAR, 1964). In order to avoid the reactions to arise due to transformation of Cibal-i Mübaha into public forests, Article 5 of the Regulation sets forth that the peasants can make use of public forests gratis or for a very low price. Thus, while the peasants were satisfied via the right of free usufruct on public forests, at the same time, the Sultanate gained a possibility for a supply of money (TUNÇS PER, 1964). This right given to peasants has been included in the Forestry Code dated 1956 and numbered 6831, and has been defined as a personal requirement. Nevertheless, after new verdicts of forestry regulation arose, countless forests were sold to leaseholders on short term or long term bases via tendering procedure; and some forest masters and leaseholders arose all around the country. As a result, not only were the forests devastated, but also the people grew poorer (DİKER, 1947). In the following section, we will treat this problem giving certain examples.

Influence of forestry regulations (1861 and 1870) on Ottoman forestry

The first Forestry Regulation, which was elaborated by French forest expert Louis Tassy and his colleagues in 1861, its revision in 1870, and the Technical and Administrative Specification Report of 41 Articles have determined the rules concerning the persons who shall engage in production activities on state-owned forests through tax collection, commitment and concession. These applications demonstrate the start of increasing governmental attention and interest on forestry activities (GÜNAY, 2003). The Forest Regulation had not been able to protect the forest; on the contrary, seeing the government taking care of forests, caused people to devastate them more than ever. Pursuant to the mentioned regulation, the Ottoman Empire, which suffered military defeats for a long time, and no longer possessed its former financial power, tried to generate some revenue via forests, at the cost of their devastation and demolition (USLU, 1951).

Forests were auctioned off, entrusted to the contractor giving the highest offer, and the contractor was shown the sections to lumber. In order to obtain revenue greater than the sum to meet his expenses, the contractor got his hands on surrounding forests, feathered his nest with these improper activities, and 
missed no chance in order to make much more profit (KANSU, 1947). The leaseholder and tax collection method could be resumed as follows: Generally, the leaseholder entered into a forestland on which there were temporary development plans, and there was an agreement to obey the plans among the parties. Even so, the leaseholder started with cutting the best trees; if he seemed unable to fulfill the requirements of the job, he applied countless ways for termination of the agreement; He left the forest after clear-cutting(ÖZEK, 1952). Hence, this method caused a great deal of devastation in forests, and for this reason, became a common subject of analysis. It will be useful to give some examples for better comprehension of the problem.

There existed contractor skid roads, descending from plateaus to villages, by which thousands of trees were transported at night (ERMER, 1949). We know very well that in 1872 , forests known as the Belova group on the upper part of the Maritsa River were given to Baron Morris De Hirsh for 35 years and processed by this person during this period; that trees of the forests on the Kacanik Mountain were cut for construction, traverses, bridge beams, station lumbers and telegraph poles for the Thessaloniki-Skopje railroad, and the firewood of all locomotives to run on this line were covered by forests on the Kacanik Mountain, and for all these requirements, 375,000 quintals of wood were spent every year; that saws of contractors cut out countless trees in the forests on mountains of Thessaly and Macedonia; that during the construction of the Suez Canal, the foreign merchants who settled in Iskenderun, together with the locals, affected cutting and delivery of the necessary wood for the canal and the new cities to be built around, so that, only some damaged coppices exist today in forests surrounding Iskenderun, and that from the 1920 s to the 1940 s, the amount of Cypriot forests decreased by $50 \%$ (BRICONGE, 1940). Çatack forests in Eski ehir were entrusted to a contractor; and this latter not only founded a lumber mill in Çatac $\mathrm{k}$, but also installed an animal railway line of $22 \mathrm{~km}$ between the Ç rçır site on the plain and Çatac k. In the end, as a result of consummation of the forest and termination of the contract, the line and the mill were removed in 1939. Because of these forests that were processed in the region, the forest sub-limit was increased from 920 meters to 1000 meters of altitude (TUNÇD LEK, 1952). Later on, we come upon similar concessions during the construction of some railroads by the foreign companies, including the lines such as Hejaz (1900-1908), Baghdad (1899-1910), and in Anatolia: Izmir-Ayd n, Izmir-Turgutlu, and Mudanya-Bursa. All along the lines of 10, 20 and 30 kilometers, these companies benefited from forests without any fee. Today if, unfortunately, we cannot see healthy forests on these routes, one of the reasons is, no doubt, these concessions (KUTLUK, 1948; ÇA LAR, 1979; GÜNAY, 2003). We can see forests in only 4 kilometers of the 400 kilometers highway between Ankara and nebolu (DAĞCI, 1949). The Zingal Company - which was established on 12.06 .1926 by the partnership of the Türkiye Kibrit İnhisar T.A. , the Türkiye Bank, and the Brussels based Ozin-Allu Metier de Flande, Belgium in order to operate the renowned Zindan and Çangal forests of Ayanc k, Sinop-is also worth analyzing. Even though the annual allowable cut for these forests were $30,000 \mathrm{~m}^{3}$, the company not only obtained an annual amount of $160,000 \mathrm{~m}^{3}$, but also chose the best trunks - which is called as selective cutting in forestry - and thus, plundered both the Zindan and Çangal forests (GÜNAY, 2003).

The handover or concession of forests to contractors for the purpose of providing income for the Treasury gave way to their devastation, as these applications did not take the continuation and future of the forests into account. As the contractor wanted to make more money by over cutting, the forest lands became ruinous and miserable. According to Article 11 of the Land Tax code dated 1931 and numbered 1833, the lands opened within the forest would be subject to tax imposition again. Hence, the land clearing in forests was indirectly tolerated (USLU, 1951). This application bears the traces of the mentality of the early Republican era, when the forests were seen as an income channel. Consequently, forest policy is under the influence of general economic policy. Therefore, a country's level of economic development and economic policy are the principal influences on forest policy (GÜMÜ ,2004), as seen once again in the above-mentioned examples. The wide forest devastation, based on the management and administration of forests by contractors and via concession, led the statesmen to line up with public ownership and administration of forests, and to give starting signal for the works aiming at this objective. The Forest Code dated 1937 and numbered 3116 - which is considered as a milestone for technical forestry in Turkeywas a kind of reaction against the devastation of countless forests like Zindan and Çangal, and also against the contractor companies. This fact can be easily understood upon a look at the justification of the code that 25.10.1935 dated and 70 serial numbered preamble, signed by the thenPrime Minister smet İnönü In the justification, the second main purpose is "to save the state-owned forests from the hands of profit-oriented contractors, thus to assure their administration directly by the government and to offer them to market from the nearest point." 
Restricting some past tenures and totally abolishing some others, the code brought along several radical regulations such as: The state ownership and administration were the main principle for forests (Article 3, 31); All forests not only belonged to the state but also were under government control (Article 4); For the first time, there was a juridical forest definition (Article 1); Past usufructs were abolished. Instead, personal requirement status would be granted for habitants of in-forest or surrounding villages for $1 / 4$ of the original fee (Article 10); Defending that public forest management could be efficient only in vast areas, the nationalization activities were legitimatized. According to temporary Article 1: The forests adjacent to public forests and owned by villagers would be nationalized in case their areas exceeded 50ha. As for others that were not adjacent to public forests, they would also be nationalized in case their areas exceeded $1000 \mathrm{ha}$; it was forbidden to permit in public forests the animals which caused serious damage, like the Angora goat, Anatolian black goat, and camel (Article 41).

\section{DISCUSSION AND CONCLUSION}

In the mid- $19^{\text {th }}$ century, as the Ottoman forestry became economically oriented, the social pressure on the forests increased more than ever. During this period, the codes and regulations coordinating forestry activities were not able to meet public requirements, and there were some shortages regarding their applications. All these facts left their mark in the memory of society.

It does not seem wrong to claim that the protection of forests and the period of technical forestry in the Republican era, both based on sustainability principles, have arisen as a reaction to the Ottoman forestry. Cibal-i Mübaha-Even today, there are villages where the forest cadastre processes are still not executed. In these villages, the peasants can claim "these forests belong to us, as we inherited them from our grandfathers." This fact proves that the Cibal-i Mübaha concept has not been totally abolished yet - tax collection and the concession system were the main motives for such reaction. Thus, strict measures, taken during the Republican era in order to preserve the forests and to equally distribute their benefits to society, might have made the living conditions harder for peasants. However, these measures gave an opportunity with respect to protection of water resources, prevention of erosion, recreational functions, and a chance for posterity to meet all these demands. Nevertheless, the forest villagers, whose access to forestry resources was restricted, have begun to migrate from villages to cities, and this phenomenon gave rise to the appearance of various socio-economic problems like unplanned urbanization, infrastructural deficiencies, accelerating pollution of water resources, lack of the ability to meet the demands concerning educational and health services, and decrease in agricultural employment.

In addition, it is possible to say that throughout its history, Turkey never experienced feudalism as in Europe. As no vast private property could be developed on the land, the Ottoman system remained different from the traditional European feudality. Also along with the Republic regime, government policy had been a negative effect on the ownership structure and management of the natural resources. These two main facts usually had negative effects on the process of the development of the private ownership over the forest lands. As a result, according to the 2009 data, the total area of private forests currently equals 15,659 ha, accounting for less than $1 \%$ of the forestland $(21,188,746 \mathrm{ha})$ in general.

As there was no concept of forest protection except the ones assigned to usage of the courts, the shipyards or the armory, a serious forest plunder occurred in Anatolia. In the republic period, as the national capital had not grown enough, the management of certain fertile forests was handed to foreign private companies. In a short time, however, these companies were virtually dismissed from the country; they destroyed the lands they took in order to manage. The structure in the Ottoman Empire and the abovementioned examples have improved the culture of protection; and today, it has become a protection instinct far from being rational and an instinctive reflex for nature conservators in Turkey. As it is seen, any present tourism-oriented project with the intention of making the natural resources subject to touristic affairs, and the works related to put the areas that have lost their forest quality, known as $2 \mathrm{~B}$, out of forest status, cause serious reactions. A rooted forestry history underlies these reflexes.

Although there are a lot of studies about land and forestry systems in the period of Ottoman Empire there are no specific studies examining the effects of this system today. This theoretical and observational study is the first study done on this issue. At the same time basic limitation of this study is absence of enough studies. Further studies using some historical resources written in Ottoman Turkish, French and German should be done. 


\section{REFERENCES}

ANONYMOUS, Cumhuriyetimizin 50. Y linda Ormanc1l $1 \mathrm{~m} \mathrm{z}$. Orman Genel Müdürlü ü Yay nı, S ra n.187, Seri n.145, 1973. 510 p.

ANONYMOUS, Ye il Kitap Orman Davam z. Türkiye Ormanc lar Derne i Yayı nı E itim Dizisi I, 2005. 81p.

ASLAN, S.; YILMAZ, A. Tanzimat Döneminde Osmanl Bürokratik Yapı ve Dü üncesinin De ișimi. C.Ü. İktisadi Ve İdari Bilimler Dergisi, 2001. V.2, Say 1, p.287-297.

BARKSIZ, A. slam ve Türk Hukukunda Orman Mülkiyeti ve Orman Sahalar nda Mülkiyet Esasları. Türk Ormanc lı inın Yüzüncü Tedris Y 1 na Girerken 18571957. Ankara, 1957. p.78-85.

BAYRAKÇI, H. Osmanl Toprak Sistemi Miri Hukuk. Marifet Yayınlan, 1990. 152p.

BERNHARD, E. Türkiye Ormanc lı ının Mevzuat . Tarihi ve Vazifeleri (Çeviren: Nihad Basri Somel). T.C. Ankara Yüksek Ziraat Enstitüsü, Say 15, 1935. 178p.

B NGÖL, İ. Ormanlar mız ve Ormancılı Im Iz, Ormanc $11 \mathrm{k}$ E itim Ve Kültür Vakf Yay nı, Yayın n.3. Cilt I, Matbaa Teknisyenleri Bası mevi, 1990. 144p.

BRİCOGNE, A. Türkiye'de Ormanc lık Heyeti, Ziraat Vekaleti Orman Genel Müdürlü ü Yay nı Sı ra 470, Sayı 3. Çeviren; Fahri Bük, Recep Usluo lu Bas mevi 1940. 136p.

ÇA LAR, Y. Türkiye'de Ormanc lı k Politikası (Dün). Ça Matbaas, 1976. 464p.

DA CI, A.N. Yeni Orman Kanunu, Orman Ve Av Dergisi, Güney Matbaac lık, 1949. Y11: 21, Say 1, p.3-4.

D KER, M. Türkiye'de Ormanc I k Dün- Bugün-Yarın, Tarım Bakanlı 1 Orman Genel Müdürlüğü Yay nı Sayı 61, 1947. $130 \mathrm{p}$.

EK ZO LU, A.; AKESEN A. Tarihi Süreç çinde Ormanc 1 k Örgütünde Görülen Yapısal Dalgalanmalar, Ormanc likta Sosyo-Ekonomik Sorunlar Kongresi Kitabı, 2006. p.157-162.

ERKAN, R. Kentle me ve Sosyal De işme. Bilim Adam Yayı nları, 2. Baskı, 2004. 287p.

ERMER, . Araç Ormanlar ndaki Etütlerden. Orman ve Av Dergisi, Güney Matbaacı lık, 1949. Y 1: 21, Sayı 1, p.10-11.

GENÇ, M. Osmanlı mparatorlu u'nda Devlet ve Ekonomi, 2009. 369p.

GÖKTÜRK, H.A. Eski ve Yeni Mülkiyet Hukukumuzda Toprak Kanunu Tasarısı Ana Prensipleri Aras ndaki Münasebetler, 1945. 27p.

GÜMÜ , C. Ormancılık Politikası. Cilt-I, Karadeniz Teknik Üniversitesi, 2004. $444 \mathrm{p}$.

GÜNAY, T. Ormanc lı mı zın Tarihçesine Kı sa Bir Bakı . Tarım Orkam-Sen Yayı n , 2003. 242p.

GÜNDÜZ, O. Türkiye'nin Bat 1 laşma Serüveninde Özgün Bir Portre: Ahmet Hamdi Tanp nar, U.Ü. Fen-Edebiyat Fakültesi Sosyal Bilimler Dergisi, 2002. Y 1: 3, Sayı: 3, p.1328 .

MAMO LU, M.A. Mülkiyet ve Toprak Sistemleri, 2006. $333 \mathrm{p}$.
KANSU, E. Ormanlar miz ve Ormancılı ımız çin Yazdıklarımız. Tar m Bakanl 1 Orman Genel Müdürlü ü Yay n, Özel Sayı 62, Çankaya Matbaas , 1947. 123p.

KESK N, Ö. Legislation Activities in Ottoman Forestry and Influence of Foreign Experts in this Subject. Journal of Forestry Faculty of Istanbul University, v.60, n.1. p.5-13, 2010. Available from: <http://www.orman.istanbul.edu.tr/ journal/index.php/orman/article/view/464/395>. Accessed: Jan. 2011

KILIC, H. Türkiye Ormanc lar Derne i ve Ormanc lık Üzerine Orhan Ataman'la Bir Söyle i. Orman ve Av, Say1: 2004-6, 2004. p.13-23.

KOÇ, B. Some Notes on 1870 Forest Nizamname' s (Regulation) Contribution to the Ottoman Forestry. Tarih Araştırmalar Dergisi, v.37, n.24, p.231-257, 2005. Available from: <http:// acikarsiv.ankara.edu.tr/browse/2235/>. Accessed: Dec. 2010.

KÖPRÜLÜ, B. Türk Hukukunda Orman Rejimi, .Ü. Hukuk Fakültesi Mecmuas, v.XIV, n.3-4, p.700-726, 1948.

KUTLUK, H. Türkiye Ormancılı le İlgili Tarihi Vesikalar. Tar m Bakanlı 1, Orman Umum Müdürlü ü, 1948. 685p. Cilt I, Yay n n.56.

KÜÇÜK, Y. Türkiye Üzerine Tezler, 1908-1978. Tekin Yay nevi, 1977. 300p

MUTLU, S. smet İnönü ve İttihat ve Terakki F rkası, C.Ü. Sosyal Bilimler Dergisi Aralı k sayısı, Cilt.30, n.2, p.125$147,2006$.

ÖZDÖNMEZ, M. Türkiye'de Orman Suçları Nevileri, Sebepleri ve Önlenmesi Çareleri Üzerine Ara tırmalar. stanbul Üniversitesi Orman Fakültesi Yayı nı, 1964. 44p.

ÖZEK, S. Orman Kanunu Davas . Orman Ve Av Dergisi, Yeni Matbaa, Cilt.24, Sayı 1, p.4-6, 1952.

SEV , R.S. Toprak Hukuku Dersleri, 1953. 479p.

TOYGAR, S. Eski Ve Yeni Hükümlere Göre Orman Anlam Ve Mülkiyet Bakım ndan Bölünü ü. Güven Basımevi, Tarım Bakanl Orman Genel Müdürlü ü Yayını, 1964. 101p. Sira n.370, Seri n.107.

TUNCCD LEK, N. İç Anadolu'nun Kuzey-Bat Bölümünde (Eski ehir Bölgesinde) Bitki Örtüsünün Da 1 na Toplu Bir Bakı , .Ü. Orman Fakültesi Dergisi, Seri B, Cilt.7, Say I, p.120-139, 1957.

TUNÇS PER, M.N. Türk Hukuk Tarihi, djare Hukuku Ve Medeni Hukukumuz Muvacehesinde Orman Mevzuat m z. Tar m Bakanlı ı Orman Genel Müdürlüğü Yayını, Sıra n.364, Sayı n.106, 107p, 1964.

USLU, M. Türkiye'de Orman Tahrip Faktörleri. Tarım Bakanlı 1 Orman Genel Müdürlü ü Yay n , Sira n.98, Seri n.10 Do uş Matbaas , 1951. 148p.

USLU, S. Türkiye'de Orman Tahribat ve Do urduğu Problemler. stanbul Üniversitesi Orman Fakültesi Dergisi, Seri B, v.23, p.40-47, 1973.

UZUNÇAR ILI, .U. Osmanl Devleti Te kilatına Medhal, 1970. 520p.

YILMAZ, B.E. Osmanl mparatorlu u'nu Di Borçlanmaya ten Nedenler ve lk D Borç. Akdeniz Üniversitesi ..B.F. Dergisi, v.1, p.186-198, 2002. 